\title{
（112）〔110]方位を有する多結晶銅板の 圧延によるすべり回転
}

\author{
上城 太 一* 関 根 和 喜**
}

Taichi Kamijo and Kazuyoshi Sekine: Slip Rotations of Polycrystalline Copper having a (112) [1]0] Orientation during Rolling. Polycrystalline copper with a (112) [110] orientation was cold-rolled up to $85 \mathrm{pct}$ and the slip rotations toward the stable end position was studied.

The normal to the rolling plane rotates toward [111] and the rolling direction toward [101]. After rolling of $85 \mathrm{pct}$, the rolling plane normal arrives at the vicinity of [123] without passing [011] and the rolling direction approaches [2i11]. Then the pure metal type texture containing (1112) [1i11] as a minor component is developed. These slip rotations can be well explained as due to the operation of slip systems bearing the highest resolved shear stress and their cross slip systems. So, the minor

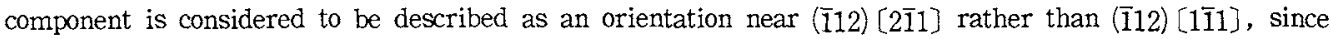
it is necessary that slip systems taking the rolling direction toward [111] must operate extensively to cause the orientation near $(\overline{1} 12)[2 \overline{1} 1]$ to displace to $(\overline{1} 12)[1 \overline{1} 1]$. In consequence, the results obtained in the present work are not consistent with the theory of Dillamore et al. which proposed the pattern $\{011\}<211>\rightarrow\{123\}<211>\rightarrow\{112\}<111>$.

$$
\text { (Received January 30, 1967) }
$$

\section{I. 緒言}

Dillamore と Roberts(1) は面心立方金属の圧延集合組織 形成の理論を提案し，2軸の応力系に対し分解せん断応力 の最も大きなすべり系の活動によつて $\{011\}<211>$ 方位 が形成されるが，交差すべりが広範囲比起こるよ5な条件 のもとでは $\{011\}<211>$ 方位は $\{123\}<211>$ に近い方位 をへて $\{112\}<111>$ 方位に変化すると主張している．

それに対して上城(2)は(001) [110]方位を有する多結晶銅 板を压延し，\{112\}<111>方位は圧延面法線之圧延方向が それぞれ標準投影図の同一大円上の $<001>-<112>$ と $<011>-<111>$ の間にある場合に普通のすべり回転によ

* 横浜国立大学工学部 (Faculty of Engineering, Yokohama National University, Yokohana)

** 横浜国立大学大学院 (Student of Graduate School, Yokohama National University, Yokohama)

(1) I. L. Dillamore and W. T. Roberts: Acta Met., 12 (1964), 281.

(2) 上城：本誌，30(1966)，415.
つて形成されると説明した。

一方上城と石井 ${ }^{(3)}$ は压延された $\{011\}<111>$ 方位の多 結晶銅板は压下率が高くなると，\{112\}<111>または $\{112\}$ ＜211>K近い方位に向かつてすべり回転することを見出 した。この方位変化は Dillamoreらが提案した $\{011\}$ $<211>$ 方位から $\{112\}<111>$ 方位への变化に類似して いるが圧延方向がく111>にある点が異なつている.

ところで压延に対し安定な (011) [2111]方位の压延面法線 と圧延方向のミラーの指数を入れ換えた (112) [110] 万位 は，2軸の応力系に対するすべり系の最大分解せ几断応力 の值は(011) [211]方位のそれと等しいが，この方位は圧延 に対し安定ではない，しかし(112)[110]方位が任延によつ てどのようなすべり回転をするかを標準投影図上で予測す ることは非常困難である.

Verbraak(4) は(112) [110]方位を有する 銅の単結晶を圧

（3）上城，石井：本誌，31 (1967)，946.

(4) C.A.Verbraak: Acta Met., $6(1958), 580$. 
延した垬合に，\{112\}<111>双鼠方位ならびに $\{011\}$ $<211>$ 方位が形成されると報告しているが，その方位变 化の経路は明示していない.

(112) [11̄0] 万位は圧延面法線と圧延方向がく001>$<111\rangle-<110\rangle$ を含む同一大円上にはないので，上城 ${ }^{(2)}$ が提案した機構で $\{112\}<111>$ 方位が 形成されることは ない。し(112)[110]方位の多結晶銅を压延した場合，压延 集合組織中心 $\{112\}<111>$ 方位が観察されれば,Dillamore らが提案した機構によつて，それが形成されたことになる 3。そのような観点から (112) [1100]方位の多結晶銅に種及 の冷間压延を施して $\{112\}<111>$ 方位発達の 過程を追跡 し, Dillamore らの理論を吟味するのが本論文の目的であ る. その際紽金属型圧延集合組織である $\{123\}<211>$ に 近い方位成分の形成についても検討することにする。

本実験では，(112)[110]方位の単結晶を用いないで， (001) [110] 万位の多結晶銅板を約 70\% 讴延することによ つて $\{112\}<111>$ 万位を作り，これを圧延面法線のまわ りに $90^{\circ}$ 回転させることにより $\{112\}<110>$ 方位の多結 晶銅板とした，したがつて最初の圧延の䟢にすべり回転, 加工硬化などがすでに生じているが，この影響はないもの と仮定し.た。

\section{II. 試料ならびに実験方法}

試料は厚さ $40 \mathrm{~mm}$ の真空溶解銅である。これを $95 \%$ の 冷間圧延後, $300^{\circ} \mathrm{C}$ で $30 \mathrm{~min}$ 焼鉠し，立方体 再結晶集合 組織を発達させてから压延方向上り $45^{\circ}$ の方向に約 70\% の 1 次圧延を施し， $\{112\}<111>$ 万位としたものである. これを $90^{\circ}$ 回転すれば，結晶の方位は $\{112\}<110>$ とな るのでささらに $32.6,56.7 ， 75.3$ 拈よび $85.4 \%$ の 2 次压延 を行なつた

各試料の (111) 怙よび (200) 極点図はX-ray Diffractometer を用いSchulz(5)の方法により決定した，吸収および 反射体積の变化位対するX線強度の補正は，同一厚さの不 規則方位を有する標準試料によつて行ない，極点圂の等高 線の高さは不規則方位の試料の $\mathrm{X}$ 線強度を基準として表わ した.

\section{III. 実 娩 結 果}

Fig.1 詁よび Fig. 2 に $\{112\}<110>$ 方位を有する基本 試料の (111) 妨上び (200) 極点図を示す。

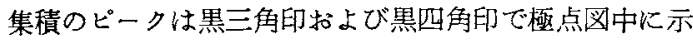
したが，正確には(449)[110]方位にある。この方位は(112) [110]方位からのずれが非常にわずかであるので，初期方 位は近似的に(112) [110] 万方位と見なしてすさしつか党な い.

圧延率 $32.6 \%$ の試料の (111) 和よび (200) 極点図を Fig.3 扣よび Fig.4 に示す。初期方位は極点図中に黒丸印なら びに半黒丸印で示してある．Fig.3を見ると，圧延力向と

(5) L.G. Schulz: J.Appl.Phys., 20 (1949), 1033.

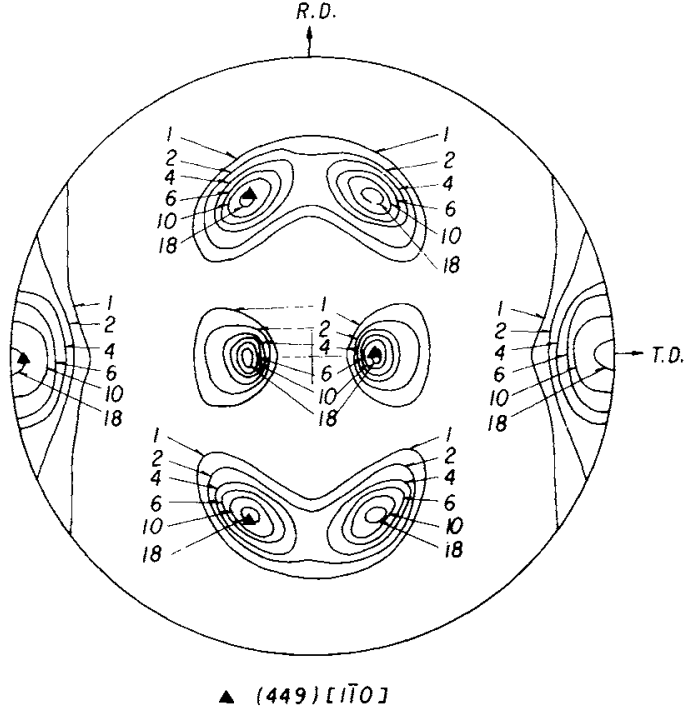

Fig.1 (111) pole figure for the rolling texture of polycrystalline copper initially with (001) [110] rolled $70 \mathrm{pct}$ and rotated $90^{\circ} \mathrm{C}$ around the axis parallel to the rolling plane normal.

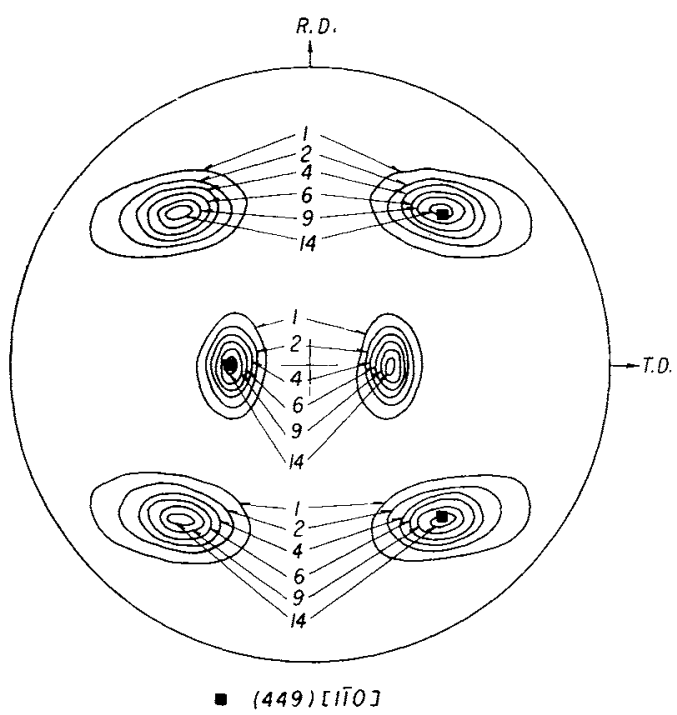

Fig.2 (200) pole figure for the same specimen as in Fig.1.

圧延面法線のおよそ中間にあつた一つの[111]極は压延方 向に近づき，横方向にあつた集積は極点图の円周方向への 分散が増すと同時にとのピークが極点図の内部へと変化乙 ていることが明らかである。 その結果,結晶は大部分 (035) 〔753]方位まで回転している.

Fig.5 招よびFig.6に，56.7\% 圧延した陚料の圧延集 合組織の (111) 括よび (200) 極点図を示す。Fig.5では，極 点図の中央部から压延方向の近傍まで連続していた集積が はつきり分離している。 その結果，集積の中心は(146) [18 $\overline{1} 1$ 10] 方位にある。 な横方向の集積は非常に低くな つている.

Fig.7 および Fig.8 亿压延率 $75.3 \%$ の試料の 压延集合 


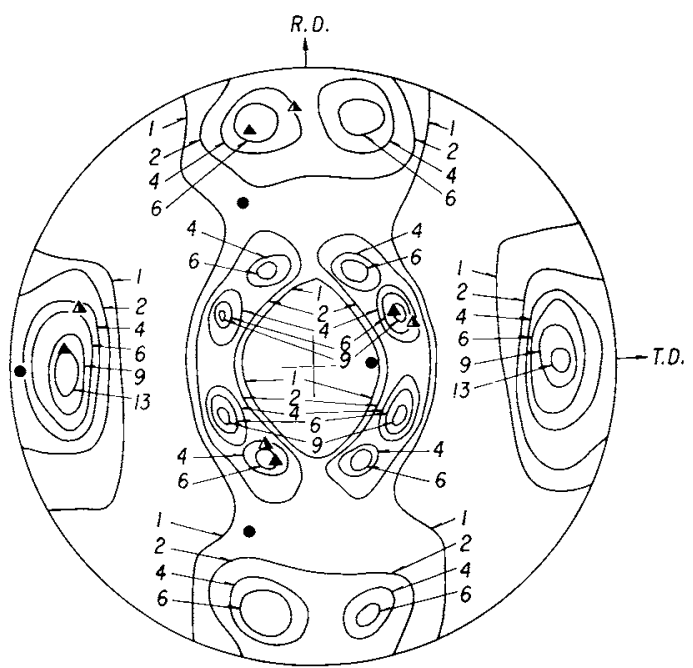

$\Delta(035)[753]$

$\Delta(1624)[3 \overline{3} 2]$

- $(449)[1102$

Fig.3 (111) pole figure for the rolling texture of copper rolled 32.6 percent.

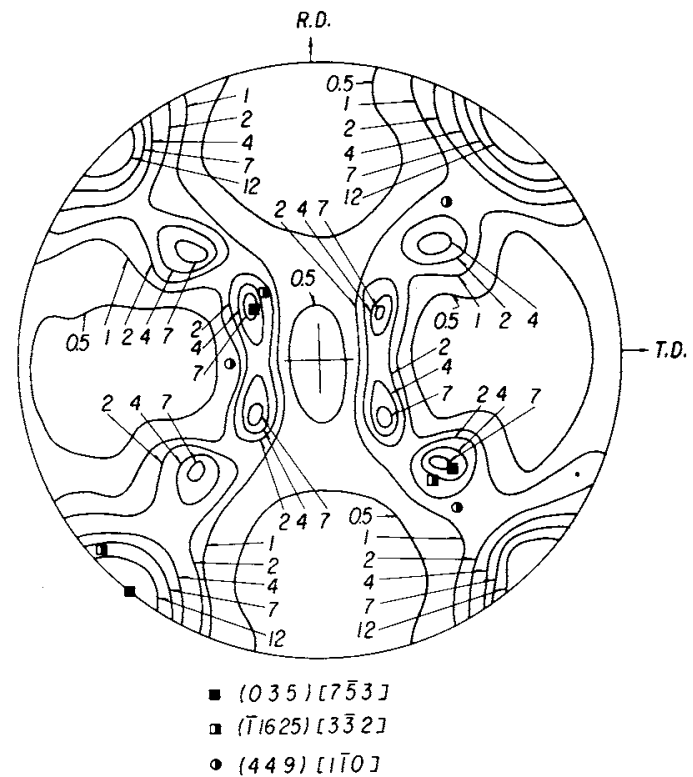

Fig.4 (200) pole figure for the same specimen as in Fig.3.

組織の(111)ならびに (200) 極点図を示す。この極点図は不 規則方位の多結晶銅板を王延した場合のそれにかなり近づ いて括り，主成分は(134)〔956」方位と記述できる。

Fig.9 と Fig.10は最子压延率の高い試料の 压延集合組 織の (111) ならびに (200) 極点図である. (111) 極点図の横 方向の集積は低いが，この圧延集合組織は不規則方位の多 結晶銅板を压延した場合のそれと類似している，そこで圧 延集合組織の主成分は，純金属型圧延集合組織のそれと一 致し，(123) [211] 方位に近い(123) [1157]方位をなつてい る。また新たに副成分として，(112）[111]方位が存在して いることが明らかである。

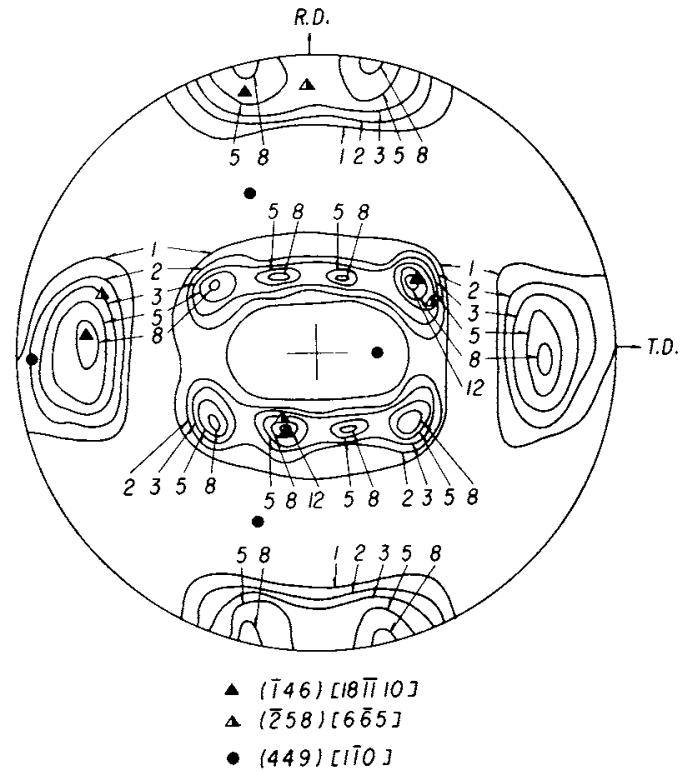

Fig.5 (111) pole figure for the rolling texture of copper rolled 56.7 percent.

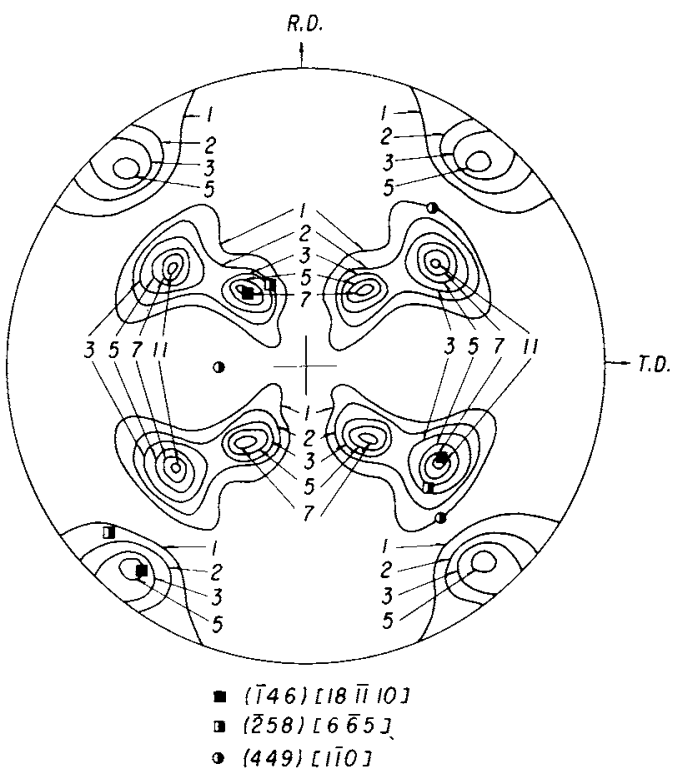

Fig.6 (200) pole figure for the same specimen as in Fig. 5.

IV. 考察

極点図によつて示した压延集合組織の变化から (112) [110]方位は (011) [2111]万位をへることなしに直接，純金 属型圧延集合組織倅変化していることがわかる，また压延 集合組織の 主成分が $\{123\}<211>$ 型の方位に 到達すると 同時に，(112)[111]方位の形成が観察されるので, Dillamore らによつて提案された $\{110\}<112>\rightarrow\{123\}<211>\rightarrow$ $\{112\}<111>$ なる方位変化は明瞭には認められない。

つぎにこの方位変化を(001) 標準ステレオ投影図上で解 析しよ5.Fig.11 は各極点図に 示した試料の主方位に対 


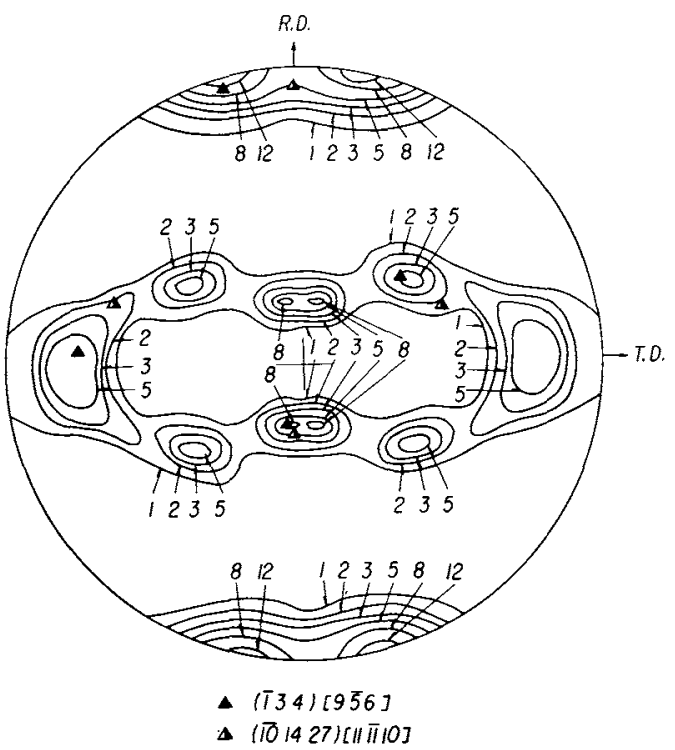

Fig.7 (111) pole figure for the rolling texture of the copper rolled 75.3 percent.

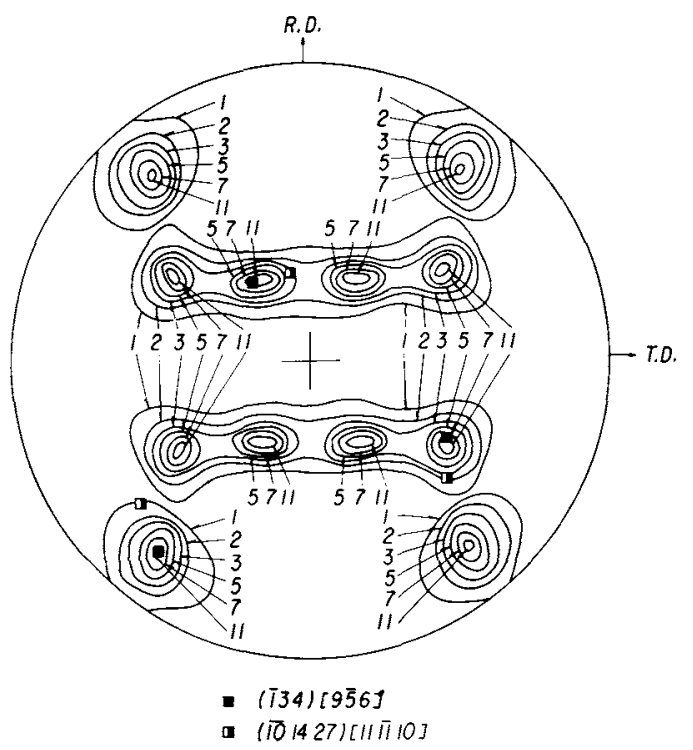

Fig.8 (200) pole figure for the same specimen as in Fig.7.

する压延面法線,压延方向执よび横方向の变化を示す $(001)$ 標準投影図である.ここで A〜Dはすべり面を，1〜6の 数字はすべり方向を表わしている。いまFig.11に示した ごとくに，圧延面法線を[449]に，压延方向を[110]にプ ロットすると，この方位に扣いては，2軸の応力系に対し て分解せん断応力最大となるすべり系はB1とD2であ る，D2が活動した場合の方位変化は，B1 のそれと等価 であるから，以後省略することにする，B1が活動した場 合には，王延面法線はBに向かつて回転し，大円[001][011]を越えて [111]に近つく。一方圧延方向は [101]に 向かつて移動するので，[2̄1]の近傍に達する・するとA5 の分解せん断応力が急速に增加しA 5 が活動するように

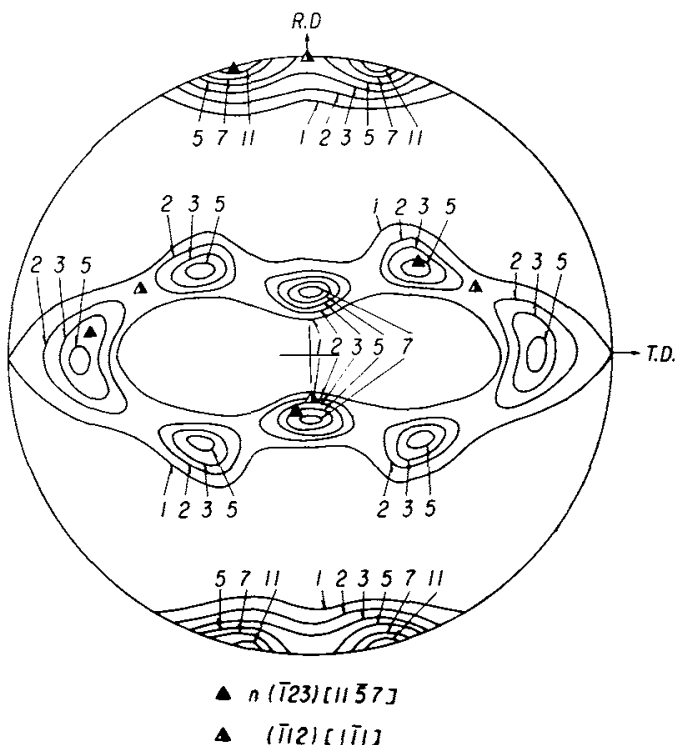

Fig.9 (111) pole figure for the rolling texture of copper rolled 85.4 percent.

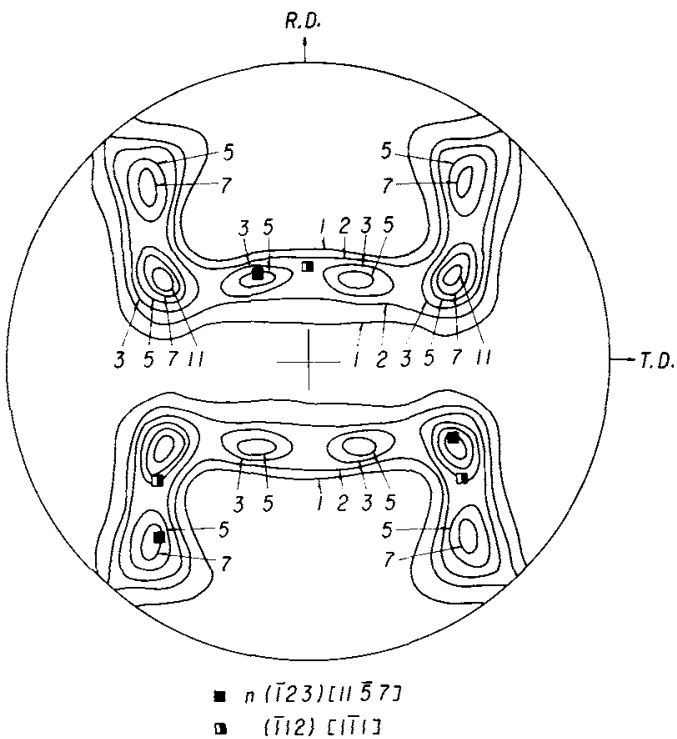

Fig.10 (200) pole figure for the same specimen as in Fig.9.

なる、そこでB1とA5が同時に活動すると考えると，

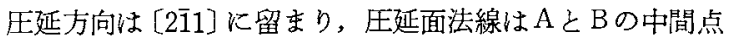
[011]に近づくはずである。ここかがFig.11に示される ごとくに，压延面法線は[011]には近つかず，[123]近傍 に達する。これはCをすべり面とするすべり系が活動した ためと推察されるが，光のようなすべり系は分解せん断応 力の值が非常に小さい，

とこちで，B1 とA5 の交差すべり系はC1とC 5 であ る. 交差すべり系はたとえ分解せん断応力が小さくても活 動することができるから，C1とC5 が作動すれば，圧延

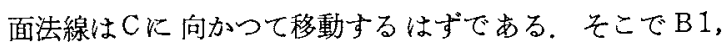
A 5 ととあに交差すべり系C 1 と C 5 が活動したと考光れ 


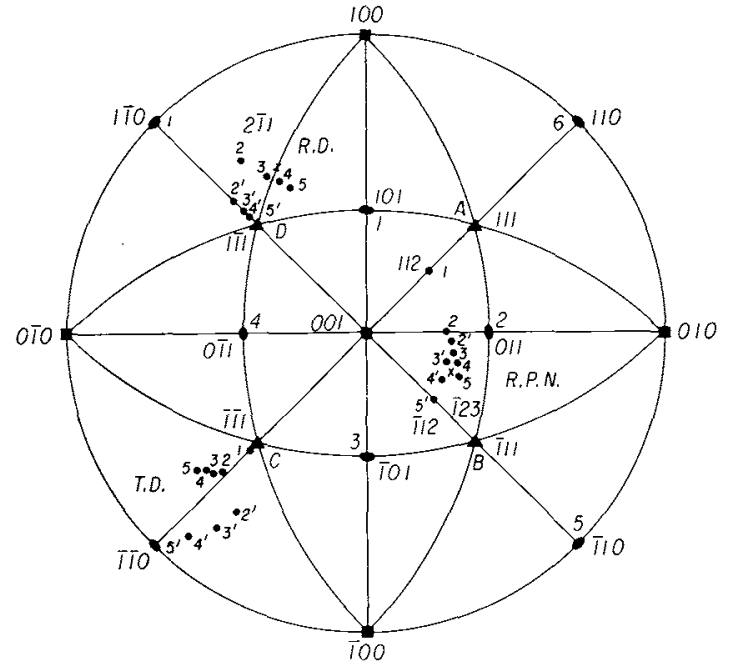

Fig.11 Standard (001) sterographic projection for cubic crystal showing slip plane $A-D$ and slip direction $1 \sim 6$. It represents also rotation of rolling plane normal, rolling direction and transverse direction twords the stable end orientations.

ば，压延面法線が [011]に近つくことができないことは理

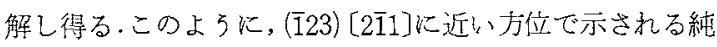
金属型圧延集合組織の形成はすで代著者の一人 ${ }^{(6)}$ 少報告し たように，分解せん断応力の最も大きなすべり系ならびに その交差すべり系の活動によつて説明することができる。

つぎに(112)〔1111]方位の成因について検討しょう，压延 集合組織の主成分が (123) [1157\}方位となると同封に (112)[111]方位の形成が認められるので，(112) [11̄0]方位 から(112)〔171]方位へ值接すべり回転する結晶る存在する ということが予想される。この上5な観点から Fig.11 に その経路を'印のついた数字で示し，この方位の極点を各 極点図に半黑三角印，ならびに半黑四角印で袁わした。こ れらの極点は各極点図に挌いて集積の中心にはないが，そ のすその部分に位置しているので，その上らな方位変化の 経路をとる結晶す存在すると考党ることがでをる。Fig.11 に物いて、[112]に向か5 圧延面法線の移動経路は[123]に 向からそれよりるCに客っているので，前者では交差すべ りがさらに広籁囲に起こつたことを示している。とこるが

(6) 上城: 本誌, $30(1966), 207$.

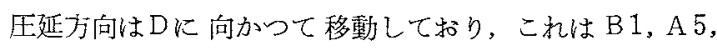
C1 执上びC 2 の活動だけでは説明できない，压延方向が

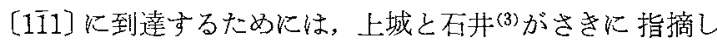
たごとく、A 4 と B 4 の活動が必要である。しかし A 4 と B 4 の分解せん断応力值は小さいのでそれが作動するとい うことは期待しがたい。したがつてそのような方位变化も 容易沈起こるとは考光られない。

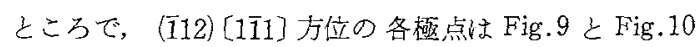
に示したように，かなり高い集積の上にあるが，これら極 点は压延集合組織の主成分の極点に非常に近いので，本当

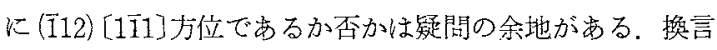
すれば，これらの集積は(112)〔111]方位ではなくて（112) 〔2111〕に近い方位成分です表現することができる。このよ ラな観点に立てば，A 4 と B 4 の活動を考劣ることなく， 交差すべりだけで圧延集合組織の副成分の形成を説明でさ るので，最す圧下率の高い試料纪存在する圧延集合組織の 副成分は $\{112\}<211>k$ 近い方位で方ると結論できる。

\section{V. 総括}

(112) [1110]方位を有する多結晶銅饭に $85.4 \%$ 以下の種 今の压延率で冷間圧延を施し, 最終安定方位洷る方位変 化の挙動を研究して，つぎのごとき結果を得た。

（1）压延面法線は [112]加ら [111] に向加つて回転し， 大円 [001]-[010]を越えて，[011]をへることなしに直接 [123]近傍に到達する。一力压延方向は [101] 晌かつて 移動し，〔211]近傍に達することにより純金属型圧延集合 組織が形成された。卆れと同時に副成分の(112)[111]方位 の形成が認められた。

(2)この力位変化は分解せん断応力最大のすべり系なら びにその交差すべり系の活動によつて説明することができ る，车の場合には副成分は(112) [111]方位よりはむしろ

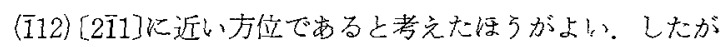
つて, 本実験の結果性 $\{011\}<211>\rightarrow\{123\}<211>\rightarrow$ $\{112\}<111>$ とい万方位変化の 経路とは一致しない.

終りに墾切なる御指導をいただいた横浜国立大学二学部 和田良澄教授, 試料を提供して下さつた古河電気工業株式 会社堀 芳郎氏ならびに実験に協力して下さつた富沢健一 阯に深く感謝いたします。 